\title{
Matrix metalloproteinase-1 expression in breast cancer and cancer-adjacent tissues by immunohistochemical staining
}

\author{
JIAJIA XUAN ${ }^{1}$, YUNFENG ZHANG ${ }^{2}$, XIUJUN ZHANG ${ }^{3}$ and FEN HU ${ }^{1}$ \\ ${ }^{1}$ College of Life Sciences, Hebei United University; ${ }^{2}$ Department of Life Sciences, Tangshan Normal University; \\ ${ }^{3}$ College of Psycology, Hebei United University, Tangshan, Hebei 063000, P.R. China
}

Received October 24, 2014; Accepted December 23, 2014

DOI: $10.3892 /$ br. 2015.420

\begin{abstract}
Although matrix metalloproteinase-1 (MMP-1) has been considered a factor of crucial importance for breast cancer cells invasion and metastasis, the expression of MMP-1 in different breast cancer and cancer-adjacent tissues have not been fully examined. In the present study, immunohistochemical staining was used to detect the MMP-1 expression in non-specific invasive ductal carcinoma of the breast, cancer-adjacent normal breast tissue, lymph node metastatic non-specific invasive ductal carcinoma of the breast and normal lymph node tissue. The results showed that MMP-1 expression is different in the above tissues. MMP-1 had a positive expression in normal lymph node tissue and lymph node metastatic non-specific invasive ductal carcinoma. The MMP-1 negative expression rate was only $6.1 \%$ in non-specific invasive ductal carcinoma of the breast and $2.9 \%$ in cancer-adjacent normal breast tissue respectively. MMP-1 expression is higher in non-specific invasive ductal carcinoma and lymph node metastatic non-specific invasive ductal carcinoma compared to cancer-adjacent normal breast tissue and normal lymph node tissue. In conclusion, higher expression of MMP-1 in breast cancer may play a crucial role in promoting breast cancer metastasis.
\end{abstract}

\section{Introduction}

Breast cancer is a pathologically and clinically heterogeneous disease, and is the most frequent malignancy among females (1). In addition, distant metastases are the most common type of breast cancer recurrence and are often the cause of fatality in breast cancer patients; metastases result in $>40,000$ fatalities per year in the USA alone (2). In a previous

Correspondence to: Professor Xiujun Zhang, College of Psycology, Hebei United University, 57 Jianshenan Road, Tangshan, Hebei 063000, P.R. China

E-mail: xiujunzhang66@126.com

Dr Fen Hu, College of Life Sciences, Hebei United University, 57 Jianshenan Road, Tangshan, Hebei 063000, P.R. China

E-mail: ihufen@126.com

Key words: matrix metalloproteinase-1, immunohistochemical staining, breast study, it was demonstrated that most complications of breast cancer are attributed to metastasis to distant organs, including lymph nodes, bone, lung and liver (3).

Matrix metalloproteinases (MMPs) are a family of zinc-dependent endoproteinases that digest components of the extracellular matrix (ECM) and cell surface receptors for soluble factors and junctional proteins involved in cell-cell and cell-ECM interactions. Due to their matrix-degrading abilities and high expression in advanced tumors, MMP activity has been shown to be required for breast cancer cell invasion and angiogenesis (4,5). MMP-1, a member of the MMP family, is upregulated in breast cancer cell lines with an enhanced ability of tumor growth, invasion and distant metastasis $(6,7)$. However, the expression of MMP-1 in breast cancer and cancer-adjacent tissues remains to be established. To address this issue, immunohistochemical staining was used to detect the MMP-1 expression in breast cancer and cancer-adjacent normal breast tissue. An extended understanding of the expression of MMP-1 may provide a novel insight into the role of MMP-1 in pathological process of breast tumorigenesis.

\section{Materials and methods}

Tissue microarray and immunohistochemical analysis. Tissue microarray purchased from Chaoying Bio-Technology Co., Ltd., (BR1002a; Xi'an, Shanxi, China). All the specimens had detailed information including age, gender, organization, pathological diagnosis, clinical grade, tumor-node-metastasis classification, clinical stage, specimen type and results.

Immunohistochemical analysis. To detect the expression of MMP-1, immunohistochemical staining was performed. Sections were heat-immobilized at $60^{\circ} \mathrm{C}$ for $30 \mathrm{~min}$ and were deparaffinized in xylene and rehydrated through a series of graded ethanol solutions. Antigen retrieval was performed in a pressure cooker at $95^{\circ} \mathrm{C}$ for 2 min using $0.01 \mathrm{M}$ citrate buffer ( $\mathrm{pH}$ 6.0). Endogenous peroxidase activity was blocked by incubation with $3 \%$ hydrogen peroxide for $15 \mathrm{~min}$ at room temperature. Sections were subsequently incubated with anti-MMP-1 mouse monoclonal antibody (1:50; sc-21731; Santa Cruz Biotechnology, Inc., Santa Cruz, CA, USA) for $60 \mathrm{~min}$ at $37^{\circ} \mathrm{C}$ in a humidified chamber. Subsequently, the sections were rinsed and incubated with a biotinylated secondary antibody for $30 \mathrm{~min}$, followed by horseradish 
Table I. Matrix metalloproteinase-1 (MMP-1) expression in breast cancer and cancer-adjacent normal tissue.

\begin{tabular}{|c|c|c|c|}
\hline Organ & Pathology diagnosis & $\begin{array}{l}\text { No. of } \\
\text { tumors }\end{array}$ & $\begin{array}{l}\text { MMP-1 } \\
\left(-,{ }^{+},++\right)\end{array}$ \\
\hline Breast & $\begin{array}{l}\text { Non-specific invasive } \\
\text { ductal carcinoma grade I }\end{array}$ & 13 & $1,6,6$ \\
\hline Breast & $\begin{array}{l}\text { Non-specific invasive } \\
\text { ductal carcinoma grade II }\end{array}$ & 12 & $0,4,8$ \\
\hline Breast & $\begin{array}{l}\text { Non-specific invasive } \\
\text { ductal carcinoma grade III }\end{array}$ & 8 & $1,3,4$ \\
\hline Breast & $\begin{array}{l}\text { Cancer-adjacent } \\
\text { normal breast tissue }\end{array}$ & 34 & $1,26,7$ \\
\hline Lymph node & $\begin{array}{l}\text { Lymph node metastatic } \\
\text { non specific invasive } \\
\text { ductal carcinoma }\end{array}$ & 9 & $0,3,6$ \\
\hline Lymph node & Normal lymph node tissue & 9 & $0,9,0$ \\
\hline
\end{tabular}

Staining was scored using a $0-2^{+}$scale. 0 means no staining; $1^{+}$and $2^{+}$indicate increased intensity of the staining. Sub-regions excluding necrosis, macrophages and infiltrated neutrophils and lymphocytes were selected and scored. The intensity score for an array spot is the average of all its sub-regions.

Table II. Different matrix metalloproteinase-1 (MMP-1) expression rates in non-specific invasive ductal carcinoma and cancer-adjacent normal breast tissue.

\begin{tabular}{lcc}
\hline Pathology diagnosis & $\begin{array}{r}\text { No. of } \\
\text { tumors }\end{array}$ & $\begin{array}{c}\text { MMP-1 expression } \\
\text { rate }(-,+,++\%)\end{array}$ \\
\hline $\begin{array}{l}\text { Non-specific invasive ductal carcinoma } \\
\text { Cancer-adjacent normal breast tissue }\end{array}$ & 33 & $(6.1,39.4,54.5)$ \\
$\begin{array}{l}\text { Lymph node metastatic non-specific } \\
\text { invasive ductal carcinoma }\end{array}$ & 9 & $(0,33.3,66.7)$ \\
Normal lymph node tissue & 9 & $(0,100,0)$ \\
\hline
\end{tabular}

peroxidase-conjugated streptavidin for $30 \mathrm{~min}$ using the UltraSensitive $^{\mathrm{TM}}$ Universal (anti-mouse/rabbit) Detection reagent (Fuzhou Maixin Biotechnology Development Co., Ltd., Fuzhou, China). Finally, the tissue microarray sections were stained with freshly prepared 3,3'-diaminobenzidine and counterstained lightly with hematoxylin. As a negative control, the primary antibody was replaced with normal rabbit or mouse immunoglobulin $\mathrm{G}$ at the same dilution. MMP-1 stain intensity was scored on a scale of 0 (negative) to $2^{+}$(intense staining).

\section{Results}

Expression of MMP-1 in breast cancer and cancer-adjacent normal tissue. The MMP-1 expression in breast cancer and cancer-adjacent normal tissue was detected by immunohistochemical staining. As shown in Table I, and Figs. 1 and 2, MMP-1 had a positive expression in normal lymph node tissue and lymph node metastatic non-specific invasive ductal carcinoma. MMP-1 had partially negative expression in non-specific invasive ductal carcinoma of the breast and cancer-adjacent normal breast tissue. The MMP-1 negative expression rate was

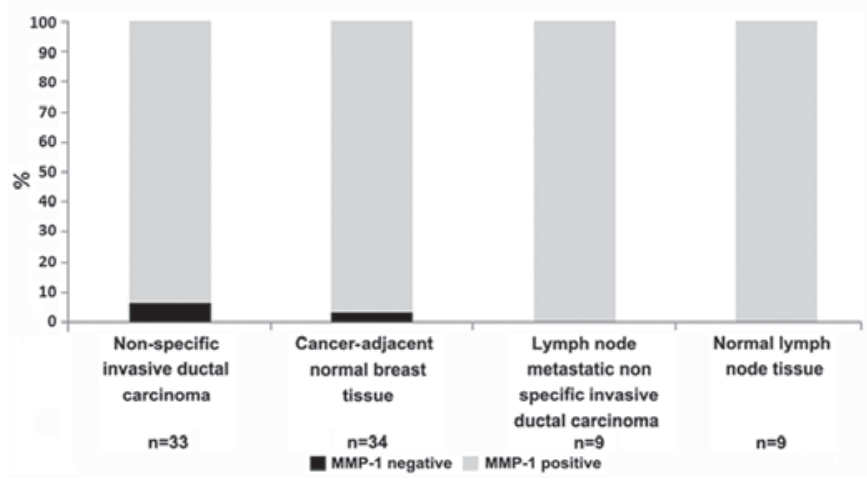

Figure 1. Positive and negative percentage analysis for matrix metalloproteinase-1 (MMP-1) expression in breast cancer tumors from 86 subjects.

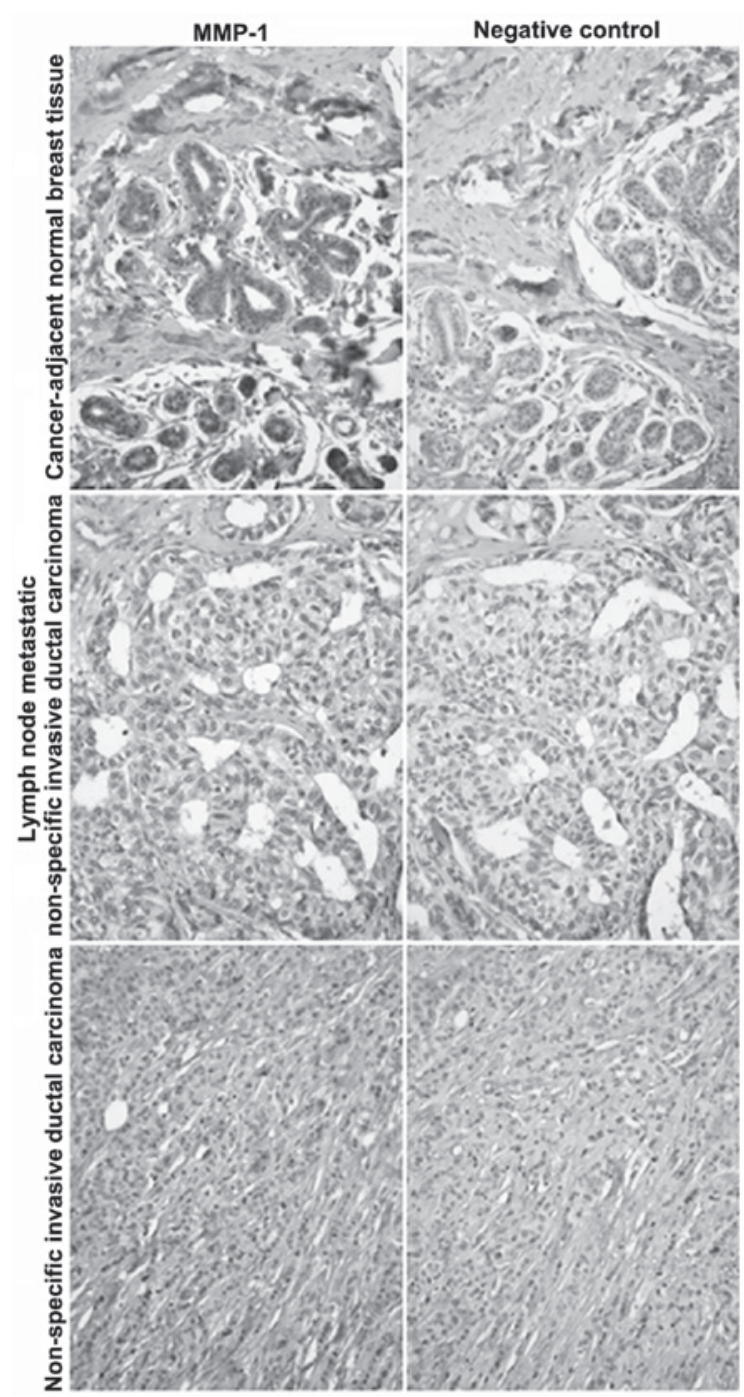

Figure 2. Representative images of immunohistochemical staining of matrix metalloproteinase-1 (MMP-1).

only $6.1 \%$ in non-specific invasive ductal carcinoma of the breast and $2.9 \%$ in cancer-adjacent normal breast tissue, respectively.

MMP-1 expression is higher in non-specific invasive ductal carcinoma compared to cancer-adjacent normal breast tissue. The MMP-1 expression rate in non-specific invasive ductal 
carcinoma and cancer-adjacent normal breast tissue, lymph node metastatic non-specific invasive ductal carcinoma and normal lymph node tissue was analyzed. As shown in Table II, the MMP-1 positive expression rate $\left({ }^{+}\right.$and $\left.{ }^{++} \%\right)$ in non-specific invasive ductal carcinoma was 39.4 and $54.5 \%$, respectively. The MMP-1 positive expression rate $\left({ }^{+}\right.$and $\left.{ }^{++} \%\right)$ in cancer-adjacent normal breast tissue was 76.5 and $20.6 \%$, respectively. The MMP-1 positive expression rate $\left({ }^{++} \%\right)$ was significantly higher in non-specific invasive ductal carcinoma compared to cancer-adjacent normal breast tissue. In addition, the MMP-1 expression rate $\left({ }^{++} \%\right)$ in lymph node metastatic non-specific invasive ductal carcinoma was $66.7 \%$, significantly more than in the normal lymph node tissue.

\section{Discussion}

MMPs are expressed in nearly all tumors, where they facilitate tumor growth, invasion and metastasis $(4,5)$. The study by Kang et al (8) used microarray analysis to show that overexpression of MMP-1 enhances MDA-MB-231 cell bone metastasis. Additionally, in breast cancer, short hairpin RNA-mediated stable knockdown of MMP-1 or induction of MMP-1 by overexpression of $\delta$-crystallin enhancer factor 1 significantly regulated the invasive ability of MDA-MB-231 (6,7). Since MMP-1 has been confirmed as a factor that facilitates breast cancer metastasis, the present study provides a novel discovery that MMP-1 expression is higher in non-specific invasive ductal carcinoma and lymph node metastatic non-specific invasive ductal carcinoma compared to cancer-adjacent normal breast tissue and normal lymph node tissue. The high expression of MMP-1 in breast cancer may be closely associated with its invasion and metastasis.

\section{Acknowledgements}

The present study was supported by grants from the National Natural Science Foundation of China (no. 81302323), the Natural Science Foundation of Hebei province (nos. C2014209140 and C2013209024), General Higher Education Young Talents Program of Hebei province (no. BJ2014027), Science and Technology Support Program of Tangshan city (no. 14120208a) and Students' Innovation and Entrepreneurship Training Program of Hebei United University (no. X2014083) and the Educational Reform Project of Tangshan Normal University (no. 2011001012).

\section{References}

1. Jemal A, Siegel R, Ward E, Hao Y, Xu J and Thun MJ: Cancer statistics, 2009. CA Cancer J Clin 59: 225-249, 2009.

2. Rugo HS: The importance of distant metastases in hormone-sensitive breast cancer. Breast 17 (Suppl 1): S3-S8, 2008.

3. Nagaiah G and Abraham J: Circulating tumor cells in the management of breast cancer. Clin Breast Cancer 10: 209-216, 2010.

4. Chabottaux V and Noel A: Breast cancer progression: insights into multifaceted matrix metalloproteinases. Clin Exp Metastasis 24: 647-656, 2007.

5. Egeblad $M$ and Werb Z: New functions for the matrix metalloproteinases in cancer progression. Nat Rev Cancer 2: 161-174, 2002.

6. Liu H, Kato Y, Erzinger SA, et al: The role of MMP-1 in breast cancer growth and metastasis to the brain in a xenograft model. BMC Cancer 12: 583, 2012.

7. Hu F, Wang C, Guo S, et al: $\delta E F 1$ promotes osteolytic metastasis of MDA-MB-231 breast cancer cells by regulating MMP-1 expression. Biochim Biophys Acta 1809: 200-210, 2011.

8. Kang Y, Siegel PM, Shu W, et al: A multigenic program mediating breast cancer metastasis to bone. Cancer Cell 3: 537-549, 2003. 